\title{
The Factors Predicting Pre-service Science Teachers' Scientific Literacy
}

\author{
Onder Cagac \\ Elementary Science Education Department, \\ Akdeniz University, 07058, Antalya/Turkey \\ E-mail: ondercagac@yahoo.com \\ Nurcan Karagol \\ Elementary Science Education Department, \\ Akdeniz University, 07058, Antalya/Turkey \\ E-mail: nurcan61996@gmail.com \\ Esme Hacieminoglu (Corresponding author) \\ Elementary Science Education Department, \\ Akdeniz University, 07058, Antalya/Turkey \\ E-mail: ehacieminoglu@gmail.com \\ ORCID: 0000-0001-9318-3931
}

\begin{abstract}
The purposes of the study are to investigate pre-service science teachers' level of scientific literacy, beliefs about science teaching, and science teaching efficacy belief and how much variance in preservice science teachers' scientific literacy can be explained by beliefs about science teaching, science teaching efficacy belief and grade point average (GPA). The survey design was used in this study and the sample of this study consisted of 172 pre-service science teachers enrolled in elementary science education department in the university. Test of basic scientific literacy, science teaching efficacy belief instrument, beliefs about science teaching questionnaire were used as data collection tools of this study. Descriptive statistics and multiple regression analyses were used as data analyses technique. Descriptive analysis results revealed that while preservice science teachers had high levels of scientific literacy and beliefs about science teaching, they had low level of personal science teaching efficacy belief. On the other hand, preservice science teachers' science teaching outcome expectancy and grade point average indicating academic achievement was acceptable level. Multiple regression analyses results revealed that preservice science teachers' academic achievement was the best predictor of the variance in preservice science teachers' scientific literacy. Besides, science content knowledge, personal science teaching efficacy belief, and beliefs about science teaching with respect to assessment made significant contribution to explaining science teachers' scientific literacy.
\end{abstract}

Key Words: Scientific literacy, Science teaching efficacy belief, Beliefs about science teaching,

DOI: $10.7176 /$ JSTR/7-05-02

\section{Fen Bilimleri Öğretmen Adaylarının Fen Okuryazarlık Düzeyini Yordayan Faktörler}

Özet

$\mathrm{Bu}$ çalışmanın amacı, fen bilimleri öğretmen adaylarının fen okuryazarlık düzeyi, fen öğretimine yönelik inançları ve fen öğretimine yönelik öz yeterlilik inançlarını betimlemek ve fen bilimleri öğretmen adaylarının fen okuryazarlığı puanındaki çeşitliliğin ne kadarının fen bilimleri öğretimine yönelik öz yeterlilik inançları, fen bilimleri öğretimine yönelik inançları ve akademik başarı puan

16 | P a g e

www.iiste.org 
ortalaması ile açıklandığını belirlemektir. Öğretmen adaylarının fen okuryazarlık, özyeterlik ve fen öğretimi inançlarını belirlemek için yapılan bu çalışmada betimsel tarama modeli kullanılmıştır. Çalışmanın örneklemini bir devlet üniversitesinde öğrenim gören 172 fen bilimleri öğretmen adayı oluşturmaktadır. Elde edilen veriler, fen okuryazarlık testi, fen öğretimine yönelik özyeterlilik inanç ölçeği ve fen öğretimine yönelik inanç ölçeği ile toplanmıştır. Veri analiz tekniklerinden betimsel analiz ve çoklu regresyon analizi kullanılmıştır. Betimsel analiz sonuçları; fen bilimleri öğretmen adaylarının fen okuryazarlık düzeylerinin ve fen öğretimine yönelik inançlarının yüksek seviyede iken, fen öğretimine yönelik bireysel öz yeterlilik inançlarının düşük seviyede olduğunu ancak akademik başarı puan ortalaması ve sonuç beklentisi bakımından orta düzeyde olduğunu göstermiştir. Bunun yanı sıra fen okuryazarlık puanlarının en iyi yordayıcısının akademik başarı puanı değişkeni olduğu tespit edilmiştir. Fen bilimleri öğretmen adaylarının fen okuryazarlık puanına tek başına en büyük katkıyı akademik başarı puanı yaparken, sırasıyla fen bilimleri konuları, fen öğretimine yönelik bireysel özyeterlilik ve değerlendirme ye yönelik inançları da anlamlı düzeyde katkı sağlamıştır.

Anahtar Kelimeler: Fen okuryazarlığı, Fen öğretimine yönelik özyeterlik, Fen öğretimine yönelik inanç

\section{Giris}

Bireylerin yaşadıkları çağa uyum sağlamaları, değişen ve gelişen koşulları takip etmeleri günümüz ve gelecek için büyük önem taşımaktadır. Bu durum eğitim ve öğretime olan ihtiyacı ortaya çıkarmıştır. Eğitimli, donanımlı, yenilikçi, problem çözme yeteneğine sahip, bilgiyi özümseyip aktarabilen bireyler geleceğin önemli güvenceleridir. Günümüzde eğitimli, yeniliklere açı ve belli bir bilgi birikimine sahip bireylerin yetiştirilmesiyle birlikte "okuryazar" kavramı da önem kazanmıștır (Kurnaz, 2019). Okuryazarlık kavramı, öğrencide var olan bilgi birikimini ve öğrencinin potansiyelini arttırarak topluma etkin bir şekilde katılmasını ve topluma faydalı bireyler olması amacıyla yazılı kaynakları keşfetme, kullanma, kabul etme ve analiz etme şeklinde ifade edilmektedir (Küçük ve Demir, 2009).

Bilim ve teknolojinin her geçen gün birey ve toplum yaşamına daha fazla entegre edilmesiyle birlikte, gittikçe kompleksleşen bu gelişmelerin anlaşılıp amacı doğrultusunda kullanılması da bir hayli zorlaşmaktadır. Bu sebeple hem bireylerin hem toplumların yeni bilimsel ve teknolojik gelişmeleri kavrayıp farkında olacak şekilde kullanabilmeleri için "fen (bilim) okuryazarı" olabilmeleri oldukça önem teşkil etmektedir (Özdemir, 2010). Günümüzde fen ve eğitim alanında yapılan çalışmaların artmasıyla birlikte fen okuryazarlığı kavramının önemi daha da artmıştır. Fen okuryazarlığ ile ilgili alan yazında birçok tanım yapılmış olmasına karşın üzerinde uzlaşılan tek bir tanım ortaya konulmamıştır.

Ülkemizde fen okuryazarlığı, Milli Eğitim Bakanlı̆̆ tarafından; araştırma-sorgulamaya istekli, etkili kararlar verebilen, problem çözme becerisine sahip, kendine inanan ve işbirliği yapabilen, iletişim kurma becerisine sahip, sürdürülebilir kalkınma bilinciyle hayat boyu öğrenen bireyler olma, fen bilimleriyle ilgili bilgi, beceri, olumlu tutum geliştirme, fen bilimlerine dair algı ve değer kazanma; fen bilimlerinin teknoloji-toplum-çevre ile olan bağlantısını kavrayabilme ve psikomotor becerileri kullanabilme gibi becerilerin bir sentezi şekilde tanımlanmaktadır (MEB, 2013). Durant (1993), ise fen okuryazarlı̆̆ın, fenle ilgili bilişsel, duyuşsal ve psikomotor becerilerin entegrasyonu şeklinde tanımlamıştır (akt. Özdemir,2010). Yapılan tanımlar göz önüne alındığında fen okuryazarlığının fen öğretimindeki önemi açıkça görülmektedir. Yolagiden (2017), yaptığı araştırmada fen öğrenme becerisi arttıkça fen okuryazarlık düzeylerinin arttığı sonucuna ulaşmıştır. Güçlüer (2012)'e göre ise, fen okuryazarlı̆̆ının önemi özellikle milletin ekonomik refahı ile ilişkilidir. Yani ulusal zenginliğin uluslararası ticarete, uluslararası rekabet gücünün ise gelişen teknoloji ve bilime bağlı olması, aynı zamanda bilimsel ve teknolojik gelişmelerin gelişmiş ülkelerde rekabet gücünü hızlandırması, dünya çapında gerçekleşen bu yarışa dahil olabilmek amacıyla bilime, teknolojiye ve bilimsel okuryazarlığa verilmesi gereken önemi açık bir şekilde göstermektedir. Bu bağlamda ülkemizde fen okuryazarlı̆̆ 1 kavramını bireylere kazandırmak oldukça önem teşkil etmektedir. Alanyazın incelendiğinde fen okuryazarlı̆̆ını etkileyen farklı değişkenlerin olduğu görülmektedir. Kurnaz (2019), yaptığı çalışmada fen okuryazarlığının cinsiyete ve evdeki bilgisayar varlığına bağlı olmadığı sonucuna ulaşmıştır. Yetişir ve Kaptan (2007)'a göre, öğrencilerin fen okuryazarı bireyler olabilmeleri için gerekli bilgi, beceri, tutum ve değerleri kazanmalarını sağlayacak önemli etmenlerden biri de öğretmendir (akt. Kaya ve Bacanak,2013). Fen bilimleri eğitimi verecek olan öğretmen adaylarının, fen okuryazarlığ1 seviyelerinin ve bu seviyeye etkili olan etmenlerin belirlenmesi, ülkemizde bilim (fen) eğitiminin niteliğinin arttırılması için önem teşkil etmektedir.

17 | P a g e

www.iiste.org 
Abd-El-Khalick vd. (1998), fen okuryazarı olan bireyi, Fen Bilimleri kapsamında bilimsel bilgi, kavram, yasa ve süreçlerden faydalanarak bilinçli kararlar verebilme becerisi kazanan birey şeklinde tanımlamışlardır(akt. Saracaloğlu, Yenice ve Özden,2013).

Laugksch (2000), fen okuryazarı olan bireyleri;

> Bilim ve toplum arasındaki ilişkileri anlayabilen

$>$ Bilim insanında olması gereken etik kuralları bilen

$>$ Bilimin doğasına dair fikri olan

> Bilim ve teknoloji kavramlarındaki farkın bilincinde olan

$>$ Bilimsel temel kavram ve teorileri bilen

> Bilim ile beşeri bilimler arasındaki ilişkileri anlayabilen bireyler olarak tanımlamıştır (akt. Yolagiden,2017).

Ders programlarında ve öğrenme-öğretme süreçlerindeki yeniliklere rağmen, fen bilimleri dersinin, öğrencilerin fen okuryazarı bireyler olma yolunda yeterli olmadığı görülmektedir. Bu amaçla, fen bilimleri eğitimi verecek olan öğretmen adaylarının, fen okuryazarlığı seviyelerinin ve buna neden olan etmenlerin belirlenmesi, ülkemizde fen eğitiminin boyutunu arttırmak için oldukça önemlidir. Ülkemizde fen bilimleri öğretmen adaylarının bu alandaki düzeylerinin belirlenmesi ve adayların doğru bir şekilde yetiştirilmesine yönelik şartların sağlanabilmesi için, bu doğrultuda yapılacak çalı̧̧malara gereksinim vardır (Özdemir,2010). Bir öğretmenin eğitimde amaçlanan başarıya ulaşması için, bunu yapabilecek inanca sahip olması gerekmektedir. Bu inançların hangi seviyede olduğu ise öz yeterlik algısına bakılarak saptanabilir (Saracaloğlu, Yenice ve Özden, 2013).

Öz-yeterlik kavramı, geçmişten günümüze olan süreçte gelişim psikolojisinden fen eğitimine, matematikten bilgisayara kadar birçok alanda, farklı değişkenlerle birlikte ele alınmıştır. Bireyin davranışlarının, bilişsel ve duyuşsal özellikleri ile çevresel farklılıkların etkileşimi sonucunda oluştuğunu belirten sosyal öğrenme kuramının içinde yer alan öz-yeterlik kavramı, bireyin varolan becerilerini ortaya koyması için ihtiyaç duyduğu etkinlikleri düzenleyip başarılı bir şekilde yapma kapasitesine dair algısıdır (Bandura, 1997).Öz-yeterlik inancı kavramının öncüsü olan ve sosyal öğrenme kuramının merkezine koyan Bandura (1986), bireylerin davranışlarının şekillenmesinde rol oynayan özyeterlik kavramını, "davranışların ortaya çıkmasına etki eden bir nitelik ve bireyin, belirli bir performansı göstermek amacıyla ihtiyaç duyduğu etkinlikleri organize ederek doğru ve başarılı bir şekilde devamını getirebilme kapasitesine dair kendine ilişkin yargısı" şeklinde tanımlamışıtır(akt. Yılmaz,2014). Senemoğlu (2013)'na göre özyeterlik, bireyin çeşitli problemlerle başa çıkması, belli bir olayı başarma becerisine ve kapasitesine ilişkin algısı, inancı ve yargısı olarak tanımlanmaktadır (akt. Karaduman,2015).

Bireylerin bazı davranışları ortaya çıkarma sırasında, gösterdikleri başarının altında yatan asıl neden özyeterlik inancının yüksek olmasıdır (Ekici, 2008). Özyeterlik, yalnızca başarı davranışlarını etkilemez. Aynı zamanda yetenek, bilgi, beceri, sonuç beklentileri ve öğrenmenin fark edilen değeri veya diğer sonuçlar için de önem taşımaktadır. Bireyler yaşamları süresince farklı problemlerle karşı karşıya kalabilirler. Bireylerin bu problemleri çözebilme gayretleri özyeterlikleriyle ilgilidir (Karaduman,2015). Öz-yeterlik kavramının etkilediği ve bu kavramla ilişkili olan önemli kavramlardan biri öğretmen öz-yeterlik algısıdır (Ekici, 2008). Öğretmenlerin ve öğretmen adaylarının mesleki yönden kendilerini yeterli görme algıları, günümüzde üzerinde çok sık durulan konulardan biri olmaktadır ve bu durumu açıklamada "öz-yeterlik inancı veya öz-yeterlik algısı" kavramları kullanılmaktadır (Yeşilyurt,2013).

Öğretmen özyeterliği, öğretmenlerin bireysel olarak, verilen eğitim hedeflerine ulaşmak amacıyla gerekli olan etkinlikleri planlayabilmeleri, organize edebilmeleri ve gerçekleştirebilmelerine ilişkin kendine olan inançları olarak kavramsallaştırılabilir (Skaalvik, Skaalvik, 2010). Aston (1984), öğretmen öz-yeterlik algılarını öğretmenlerin, öğrencilerin performanslarına etki edebilme düzeyleri veya görevlerini uygun ve doğru bir şekilde yapmaları için ihtiyaç duydukları davranışları sergileyebilecekleri konusundaki algıları şeklinde tanımlamıştır (akt. Yenice, 2012). Atıcı (2000)'ya göre, öğretmen öz-yeterlik inancı, öğretmenlerin öğretimi başarılı bir şekilde gerçekleştirebilmesi amacıyla istendik davranışları ortaya çıkarmadaki inanışlarıdır (akt. Yılmaz, 2014). Smith (1996)'e göre öğretmenin öz yeterliği, sinıfta uygulanacak etkinliklerin ve bunun etkinliklerin sonucunda öğrencilerde ortaya çıkacak öğrenmeleri önemli ölçüde etkilemektedir. Düşük öz yeterliği olan öğretmenler, sınıf yönetimi konusunda katı ve kuralcı olup öğrencilerin öğrenme becerilerine yönelik

18| P a g e

www.iiste.org 
olumsuz bakış açıları ortaya koymaktadır (akt. Aldan Karademir,2013). İlköğretim düzeyinde fen öğretimi yapacak olan öğretmen adaylarının, öğretmenliğin ilk aşamasındaki öğretmen eğitimi boyunca kazandıkları öğrenme yaşantıları, onların öğretmenlik yaşamı boyunca kullanacakları öğrenme öğretmeye yönelik inançlarına etki edebilir (Y1lmaz ve Eren, 2014). Chan ve Elliott (2004)'e göre, öğrenme öğretme anlayışı, öğretmenlerin öğretim sürecince benimsedikleri öğretme-öğrenme stratejilerine yönelik inançlarını ortaya koymaktadır (akt. Yener ve Yılmaz,2017). Yapılan araştırmalar incelendiğinde öğretmen adaylarının özyeterlik algısının ve öğretmeye yönelik inançlarının farklı değişkenlere bağlı olduğunu ortaya koymaktadır. Demirtaş, Cömert ve Özer (2011), yaptıkları çalı̧̧mada öğretmen adaylarının öz-yeterlik algılarının cinsiyet ve öğrenim görülen program değişkenlerine göre anlamlı şekilde farklılaştığını bulmuşlardır. Saracaloğlu, Yenice ve Özden (2013) ise, yaptıkları çalışmada fen bilimleri öğretmen adaylarının Fen ve Teknoloji okuryazarlı̆̆ına yönelik özyeterlik algı düzeylerinin "oldukça yeterli" olduğunu ortaya koymuşlardır. Yeşilyurt(2013) ise, öğretmen adaylarının öğretmen öz-yeterlik algısını belirlediği çalışmanın sonucunda, cinsiyet, öğretmen olarak görev yapma-yapmama ve öğrenim görülen program türü değişkenleri yönünden anlamlı farklılık tespit ederken, akademik başarı notu değişkeni yönünde anlamlı bir farklılık bulunamamıştır. $\mathrm{Bu}$ durumlar dikkate alındığında, fen bilimleri eğitimi verecek olan öğretmen adaylarının, hem fen okuryazarlığı düzeylerinin, hem de öğretmen özyeterlik algılarının istendik düzeyde olması, ülkemizde bilim (fen) eğitiminin niteliğinin artırılmasında ve ülkenin geleceğini üstlenecek bireylerin yetiştirilmesinde önemli oranda rol oynayacaktır.

Bu nedenle yapılan çalışmanın amacı;

(1) Fen bilimleri öğretmen adaylarının fen okuryazarlık düzeyi, fen öğretimine yönelik inançları ve fen öğretimine yönelik özyeterlik inançlarını betimlemek,

(2) Fen Bilimleri öğretmen adaylarının fen okuryazarlığı puanlarındaki çeşitliliğin ne kadarının fen bilimleri öğretmen adaylarını fen bilimleri öğretimine yönelik öz yeterlik inançları, fen bilimleri ögretimine yönelik inançları ve akademik başarı puan ortalaması ile açıklandığını belirlemektir.

\section{Yöntem}

Yöntem bölümünde; araştırmanın modeline, araştırmanın çalışma grubuna, araştırmada kullanılan veri toplama araçlarına ve verilerin analizine ait bilgiler bulunmaktadır.

\subsection{Araştırma Modeli}

Yapılan araştırmada nicel araştırma yöntemlerinden tarama modeli tercih edilmiştir. Karasar (2009)' a göre; tarama modelinde olaylar ve bireyler, kendi bulunduğu koşullar altında ve değiştirilmeden tarif edilir (akt. Yağan, 2019).

\section{2 Çalışma Grubu}

Uygun örneklem yöntemi seçilmiş bu araştırmanın örneklemini bir devlet üniversitesinde öğrenim gören 172 üçüncü sinıf fen bilimleri öğretmen adayı oluşturmuştur.

\section{3 Veri Toplama Araçları}

\subsubsection{Temel Fen Okuryazarlığı Testi (Test of Basic Scientific Literacy)}

Fen bilimleri öğretmen adaylarının fen okuryazarlığı düzeylerini belirlemek için kullanılan Laugksch ve Spargo (1996)'nun geliştirdiği Temel Fen Okuryazarlığı Testi toplam 3 alt boyuttan ve 110 maddelik yargı ifadelerinden oluşmaktadır. Test 72 maddeden oluşan Bilimsel İçerik Bilgisi, 22 maddeden oluşan Bilimin Doğası ve 16 maddeden oluşan Fen - Teknoloji - Toplum - Çevre Etkileşimi alt boyutlarını içermektedir.

2.3.2 Fen Öğretimi Özyeterlik İnanç Ölçeği (Science Teaching Efficacy Belief Instrument (STEBI-B)) Fen bilimleri öğretmen adaylarının fen öğretimine yönelik özyeterlik inanç düzeylerini belirlemek için Riggs ve Enochs (1990)'un geliştirdiği Fen Öğretimi Yeterlilik İnanç Ölçeği kullanılmıştır. Ölçek, Tekkaya, Çakıroğlu ve Özkan (2004) tarafindan Türkçe'ye adapte edilmiştir. Ölçek, 13 maddeden oluşan bireysel fen öğretimi yeterlilik inancı (personal science teaching efficacy) ve 10 maddeden oluşan fen öğretimi sonuç beklentisi (science teaching outcome expectancy) olmak üzere 2 boyuttan oluşmaktadır. 5'li Likert tipinde hazırlanan ölçek toplam 23 maddeden oluşmaktadır ve ölçeğin

19| P a g e

www.iiste.org 
Cronbach güvenirlik katsayıları sırasıla .89 ve .76 olarak belirlenmiştir. Türkçeye adapte edilen çalışmada ise ölçeğin Cronbach güvenirlik katsayıları sırasıyla .84 ve .76 olarak rapor edilmiştir.

\subsubsection{Fen Öğretimine yönelik İnanç Ölçeği (Beliefs about Science Teaching)}

Fen Bilimleri Öğretmen adaylarının fen öğretimine ilişkin inanç seviyelerini belirlemek için YilmazTuzun (2008)'ün geliştirdiği fen öğretimine yönelik inanç ölçeği kullanılmıştır. Araştırmacılar tarafından Türkçe ye çevrilen ölçeğin 2 bölümü bulunmaktadır. Ölçeğin birinci bölümü, öğretim yöntemleri (Instructional Methodologies) (18 madde), değerlendirme (Assessments) (12 madde) ve sınıf yönetimi (Classroom Managements) (25 madde) olmak üzere 3 alt boyuttan oluşmaktadır. Ölçeğin ikinci bölümü, fen bilimleri öğretmen adaylarının müfredat taki konuları ne kadar etkili öğretebileceklerine yönelik konu başlıklarını içeren (67 madde) konu başlığından oluşmaktadır. Ölçeğin orjinalindeki ikinci bölümü uygulamadan önce ülkemize ait ortaokul fen bilimleri programındaki konulara göre düzenlenmiştir.

\subsection{Verilerin Analizi}

$\mathrm{Bu}$ çalışmadaki veriler SPSS 23 paket programı kullanılarak analiz edilmiştir. Fen bilimleri öğretmen adaylarının fen okuryazarlık, özyeterlik ve fen öğretimi inançların belirlemek için betimsel analiz yapılırken, fen bilimleri öğretmen adaylarının fen okuryazarlık puanlarındaki çeşitliliğin ne kadarının fen bilimleri öğretimine yönelik öz yeterlik inançları, fen bilimleri öğretimine yönelik inançları ve akademik başarı puanı ile açıklandığı çoklu regresyon analizi ile belirlenmiştir.

\section{Bulgular}

Betimsel istatistik sonuçlarına göre; fen bilimleri öğretmen adaylarının fen okuryazarlığı, fen öğretimine yönelik inanç, fen öğretimi öz yeterlilik inancı ve akademik başarı puanına ilişkin sonuçlar Tablo 1 de gösterilmiştir.

Tablo 1: Fen Bilimleri öğretmen adaylarının fen okuryazarlığı, fen öğretimine yönelik inanç, fen öğretimi öz yeterlilik inancı ve akademik başarı puanı ile ilgili betimsel istatistik tablosu

\begin{tabular}{|c|c|c|c|c|}
\hline & & $\mathrm{X}$ & SS & $\mathrm{N}$ \\
\hline Fen Okur Yazarlığı & Fen okuryazarlığ1 & 82,96 & 15,61 & 172 \\
\hline \multirow{3}{*}{$\begin{array}{l}\text { Fen Öğretimine yönelik İnanç } \\
\text { (Bölüm 1) }\end{array}$} & Öğretim yöntemleri & 3,95 & 0,54 & 172 \\
\hline & Değerlendirme & 3,92 & 0,53 & 172 \\
\hline & Sınıf Yönetimi & 3,95 & 0,54 & 172 \\
\hline $\begin{array}{l}\text { Fen Öğretimine yönelik İnanç } \\
\text { (Bölüm 2) }\end{array}$ & $\begin{array}{l}\text { Fen bilimleri konuları } \\
\text { Müfredat bilgisi } \\
\text { (İçerik Bilgisi) }\end{array}$ & 3,96 & 0,55 & 172 \\
\hline \multirow[t]{3}{*}{ Fen Öğretimi Özyeterlilik İnancı } & Sonuç beklentisi & 3,47 & 0,55 & 172 \\
\hline & $\begin{array}{l}\text { Bireysel fen öğretimi } \\
\text { öz yeterliliği }\end{array}$ & 2,76 & 0,27 & 172 \\
\hline & Fen başarı puanı & 2,92 & 0,49 & 166 \\
\hline
\end{tabular}

Tablo 1'de elde edilen bilgiler doğrultusunda; fen bilimleri öğretmen adaylarının fen okuryazarlık puan ortalaması 82,96 ve standart sapması 15,61' dir. Fen öğretimine yönelik inanç birinci bölümü bulgularına göre; öğretim yöntemleri inanc1 puan ortalaması 3,95 ve standart sapması 0,54 , değerlendirme inancı puan ortalaması 3,92 ve standart sapması 0,53 , sinıf yönetimi inancı puan ortalaması 3,95 ve standart sapması 0,54 ' dür. Fen öğretimine yönelik inanç ikinci bölümü bulgularına göre; müfredat bilgisi inancı puan ortalaması 3,96 ve standart sapması 0,55 ' dir. Fen öğretimi özyeterlilik inancı bulgularına göre; sonuç beklentisi puan ortalaması 3,47 ve standart sapması 0,55 'dir. Bireysel fen ögretimi öz yeterliliği puan ortalaması 2,76 ve standart sapması 0,27 , fen başarı puan ortalamas1 2,92 ve standart sapmasi $0,49^{\prime}$ dur.

Betimsel analiz sonuçları, fen bilimleri öğretmen adaylarının fen okuryazarlık düzeylerinin ve fen öğretimine yönelik inançlarının tüm alt boyutlarda (öğretim yöntemleri, değerlendirme, sınıf yönetimi, içerik bilgisi) yüksek seviyede iken, fen öğretimine yönelik bireysel öz yeterlilik inançlarının düşük 20| P a g e 
seviyede olduğu ancak akademik başarı puan ortalaması ve sonuç beklentisi bakımından orta düzeyde olduğunu göstermiştir.

3.1. Fen Bilimleri Öğretmen Adaylarının Fen Okuryazarlı̆̆ı Puanını Yordayan Değişkenlere İlişkin Çoklu Regresyon Analizi Sonuçları

Fen Bilimleri öğretmen adaylarının fen okuryazarlığı puanlarındaki çeşitliliğin ne kadarının fen bilimleri eğitimine yönelik öz yeterlik inançları, fen öğretimine yönelik inançları ve akademik başarı puanı ile açıklandığını belirlemek için çoklu regresyon analizi kullanılmıştır. Varsayımlar kontrol edildiğinde; çoklu doğrusal bağlantı varsayımı regresyon modelindeki bağımsız değişkenlerin aralarında bir bağlantı olması durumudur. Bağımsız değişkenler arasında böyle bir ilişki olması testin güvenilirliğini azaltmaktadır. Bu çalışmada Tolerance değeri $0,1^{\prime}$ in üzerindedir ve VIF değeri de 10 ' un altındadır. Bu değerler istenilen değerler aralı̆̆ındadır.

Tablo 2: Fen bilimleri öğretmen adaylarının fen okuryazarlığı puanını yordayan değişkenlere ilişkin korelasyon matriksi

\begin{tabular}{lcccccccc}
\hline & 1 & 2 & 3 & 4 & 5 & 6 & 7 & 8 \\
\hline Fen Okuryazarlı̆ı (1) & 1.00 & & & & & & & \\
\hline Öğretim Yöntemleri (2) & .264 & 1.00 & & & & & & \\
\hline Değerlendirme (3) & .314 & .607 & 1.00 & & & & & \\
\hline Sinıf Yönetimi (4) & .264 & 1.00 & .607 & 1.00 & & & & \\
\hline Fen Bilimleri Konuları (5) & .350 & .616 & .605 & .616 & 1.00 & & & \\
\hline Sonuç Beklentisi (6) & .012 & .046 & -.004 & .046 & .135 & 1.00 & & \\
\hline $\begin{array}{l}\text { Bireysel Fen Öğretimi } \\
\text { özyeterlik inancı (7) }\end{array}$ & -.338 & -.168 & -.054 & -.168 & -.156 & -.124 & 1.00 & \\
\hline Başarı Puan Ortalaması (8) & .338 & .042 & -.035 & .042 & -.065 & -.163 & -.273 & 1.00 \\
\hline
\end{tabular}

Tablo 2' deki bilgiler doğrultusunda; fen bilimleri öğretmen adaylarının fen okuryazarllğı ile yordayıcı değişkenler arasındaki ilişki pozitif - negatif ve .3 e yakın ve üzerindedir. Yordayıcı değişkenlerden öğretim yöntemleri, sınıf yönetimi ve sonuç beklentisi değişkenleri ile olan korelasyon sırasıyla $.264, .264$ ve .012 ' dir ve bu nedenle modele alınmamıştır.

Tablo 3: Fen bilimleri öğretmen adaylarının fen okuryazarlığı puanının yordanmasına ilişkin çoklu regresyon analizi sonuçları ve regresyon eşitliğ $i$

\begin{tabular}{|c|c|c|c|c|c|c|c|}
\hline Değişken & Çoklu R & $\mathrm{R}^{2}$ & $\mathrm{R}^{2}$ Değişimi & F Değişimi & sd1 & $\operatorname{sd} 2$ & F Değişim P \\
\hline Fen bilimleri konuları & .350 & .123 & .123 & 22.918 & 1 & 164 & .000 \\
\hline $\begin{array}{l}\text { Fen bilimleri konuları } \\
\text { Başarı puanı }\end{array}$ & .503 & .253 & .131 & 28.551 & 1 & 163 & .000 \\
\hline $\begin{array}{l}\text { Fen bilimleri konuları } \\
\text { Başarı puanı } \\
\text { Bireysel fen öğretimi } \\
\text { özyeterlik }\end{array}$ & .538 & .290 & .036 & 8.313 & 1 & 162 & .004 \\
\hline $\begin{array}{l}\text { Fen bilimleri konuları } \\
\text { Başarı puanı } \\
\text { Bireysel fen öğretimi } \\
\text { özyeterlik } \\
\text { Değerlendirme }\end{array}$ & .556 & 309 & .019 & 4.402 & 1 & 161 & .037 \\
\hline
\end{tabular}

Tablo 3 incelendiğinde; araştırmanın örneklemini oluşturan fen bilimleri öğretmen adaylarının fen okuryazarlı̆ğ puanlarını yordanmasına ait çoklu regresyon analizi dört aşamada yapılmıştır. Fen bilimleri konularına yönelik inançları, başarı puanı, bireysel fen öğretimi özyeterlik inancı ve fen bilimleri öğretimine yönelik değerlendirme alt boyuna yönelik inanç değişkenleri anlamlı yordayıcılar olarak bulunmuştur. Birinci aşamada, öğretmen adaylarının fen okuryazarlık puanının yordayıcısı ya da fen okuryazarlık puanlarındaki varyansın açıklayıcısı olarak fen bilimleri konuları (içerik bilgisi)

21 I P a g e www.iiste.org 
değişkeni, fen okuryazarlık varyansının \%12,3 ‘ünü açıklamaktadır. Fen bilimleri konuları ile fen okuryazarlık puanları arasındaki ikili ilişki pozitif yönlü ve istatistiksel olarak anlamlıdır. ( $R=, 350$, $\left.\mathrm{R}^{2}=, 123, \mathrm{~F}=22,918, \mathrm{p}<, 001\right)$. İkinci aşamada, fen bilimleri konuları değişkenine ek olarak fen okuryazarlık puanının en iyi yordayıcısı veya fen okuryazarlık puanlarındaki varyansın en iyi açıklayıcısı olarak fen bilimleri başarı puan ortalaması değişkeni analize eklenmiş ve \%13.1 'lik bir ek katkı getirmiş olup iki değişken birlikte fen okuryazarlı̆ğ puanı toplam varyansını \% 25.3 'e ç̧ıarmıştır. Fen bilimleri başarı puan ortalaması değişkeni ile fen okuryazarlık puanları arasındaki ikili ilişki pozitif yönlü ve istatistiksel olarak anlamlıdır. $\left(\mathrm{R}=, 503, \mathrm{R}^{2}=, 253, \mathrm{~F}=28,551 \mathrm{p}<, 001\right)$. Üçüncü aşamada fen bilimleri konuları ve fen bilimleri başarı puanı değişkenlerine ek olarak fen okuryazarlık puanı varyansına katkı sağlayan bireysel fen öğretimi özyeterlik inancı değişkeni analiz edilmiştir. Son değişkenin ilave katkısı \%3,6’ dır. Üç değişken, fen okuryazarlık puanı varyansını \%29'a yükseltmiş̧tir. Fen bilimleri öğretmen adaylarının bireysel fen öğretimi özyeterlik inancı ve fen okuryazarlık puanı arasındaki ikili iliş̧ki istatistiksel olarak anlamlıdır. $\left(\mathrm{R}=, 538, \mathrm{R}^{2}=, 290, \mathrm{~F}=8,313, \mathrm{p}<.005\right)$ Dördüncü aşamada fen bilimleri konuları, fen bilimleri başarı puanı ve bireysel fen öğretimi özyeterlik inancı değişkenlerine ek olarak fen okuryazarlık puanı varyansına katkı sağlayan fen bilimleri öğretimine yönelik değerlendirme alt boyutuna ile ilgili inançları değişkeni analiz edilmiştir. Son değişkenin getirdiği ilave katkı \%1,9'dur. Dört değişken, fen okuryazarlık puanı varyansını \%30.9'a çıkarmıştır. Fen bilimleri öğretmen adaylarının değerlendirme ile ilgili inancı ve fen okuryazarlık puanı arasındaki ikili ilişki istatistiksel olarak anlamlıdır. $\left(\mathrm{R}=, 556, \mathrm{R}^{2}=, 309, \mathrm{~F}=4,402, \mathrm{p}<.005\right)$.

Tablo 4: Fen bilimleri Öğretmen Adaylarının Fen Okuryazarlık Puanlarının Yordanmasına Ait Sonuç Tablosu

\begin{tabular}{lccccc}
\hline Değişken & $\mathrm{B}$ & Std Hata & Beta & $\mathrm{T}$ & $\mathrm{P}$ \\
\hline (Sabit) & 43.966 & 8.226 & & 5.345 & .000 \\
Fen bilimleri konuları & .370 & 2.055 & .350 & 4.787 & .000 \\
\hline (Sabit) & 8.064 & 10.153 & & .794 & .428 \\
Fen bilimleri konuları & 10.493 & 1.905 & .374 & 5.508 & .000 \\
Başarı puanı & 11.383 & 2.130 & .362 & 5.343 & .000 \\
\hline (Sabit) & 48,512 & 17.189 & & 2.822 & .005 \\
Fen bilimleri konuları & 9,506 & 1.895 & .338 & 5.016 & .000 \\
Başarı puanı & 9,579 & 2.176 & .305 & 4.402 & .000 \\
Bireysel fen öğretimi & -11.319 & 3.926 & -.202 & -2.883 & .004 \\
özyeterlik & & & & & \\
\hline (Sabit) & 42.138 & 17,280 & & 2.439 & .016 \\
Fen bilimleri konuları & 6.529 & 2.352 & .232 & 2.776 & .006 \\
Başarı puanı & 9.485 & 2.154 & .302 & 4.403 & .000 \\
Bireysel fen öğretimi & -11.770 & 3.891 & -.210 & -3.025 & .003 \\
özyeterlik & & & & & \\
Değerlendirme & 5.014 & 2.390 & .173 & 2.098 & .037 \\
\hline
\end{tabular}

$Y$ davranıs $=42.138+6.529 X$ Fen bilimleri konuları +9.485 X Başarı puanı $+(-11.770)$ X Özyeterlik $+5.014 X$ Değerlendirme

$Y$ davranış $=.232 X$ Fen bilimleri konuları $+.302 X$ Başarı puanı $-.210 X$ Özyeterlik $+.173 X$ Değerlendirme

Tablo 4 ve modele ait formüller incelendiğinde fen bilimleri öğretmen adaylarının fen okuryazarlık puanına tek başına en büyük katkıyı başarı puanı $(\beta=.302)$ yaparken, sırasıyla fen bilimleri konuları (içerik bilgisi) $(\beta=.232)$, bireysel fen öğretimi özyeterlik $(\beta=-.210)$ ve değerlendirme $(\beta=.173)$ fen bilimleri öğretmen adaylarının fen okuryazarlı̆̆ puanlarındaki çeşitliliğe anlamlı düzeyde katkı sağlamıştır.

\section{Sonuç, Tartışma ve Öneriler}

$\mathrm{Bu}$ çalışmanın amacı, fen bilimleri öğretmen adaylarının fen okuryazarlık düzeyi, fen öğretimine yönelik inançları ve fen öğretimine yönelik öz yeterlilik inançlarını betimlemek ve fen bilimleri öğretmen adaylarının fen okuryazarlığı puanındaki çeşitliliğin ne kadarının fen bilimleri öğretimine

22 | P a g e

www.iiste.org 
yönelik öz yeterlilik inançları, fen bilimleri öğretimine yönelik inançları ve akademik başarı puan ortalaması ile açıklandığını belirlemektir.

Bulgular kısmındaki veriler ıșığında fen bilimleri öğretmen adaylarının fen okuryazarlık puan ortalamasının yüksek seviyede olduğu sonucuna ulaşılmıştır. Gökdemir (2020), 236 fen bilimleri öğretmen adayının PISA fen okuryazarlı̆̆ının araştııılması adlı yaptığı araştırmasında hem kâğıt-kalem testine hem bilgisayar tabanlı teste katılan katılımcıların tüm sınıflar düzeyindeki başarı ortalamaları dikkate alındığında, kâğıt-kalem testindeki başarı ortalamasının da yüksek seviyede olduğu sonucuna ulaşmışıtır.

Bunun yanı sıra fen bilimleri öğretmen adaylarını fen öğretimi inanç düzeyi öğretim yöntemleri bakımından yüksek seviyede değerlendirme açısından yüksek seviyede, sınıf yönetimi bakımından yüksek seviyede ve müfredat bilgisi bakımından da yüksek seviyede olduğu sonucuna ulaşılmıştır. Ölçeğe verilen cevaplar incelendiğinde öğretim yöntemleri boyutunda öğretmen adayları "Şu anki bilgilerime göre aşağıdaki metotları kullanarak öğretim yapabileceğime inanıyorum" başlığı altında fikirlerini beyan etmişlerdir. Öğretmen adayları "kesinlikle katıllyorum" veya "katıllyorum" ifadelerini kullanarak buluş, keşfetme, işbirlikli öğrenme, çoklu zeka kuramı, analoji, tartışma, örnek olay gibi bir çok öğretim yöntem ve tekniğini kullanarak öğretim yapabileceğini belirtmişken öğretmen adaylarının \%29 u "kesinlikle katılmıyorum" veya "katılmıyorum" ifadelerini kullanarak düz anlatımı etkili olarak kullanamayacaklarını \% 20 ye yakını ise yapılandırıcı öğrenme yaklaşımı, proje tabanlı öğrenme, öğrenme halkası, kavramsal değişim yaklaşımı, altı şapkalı düşünme, ve argümentasyon u etkili olarak kullanamayacaklarını belirtmişlerdir.

Değerlendirme boyutunda öğretmen adayları "Şu anki bilgilerime göre aşağıdaki değerlendirmeleri kullanarak öğrencilerin başarılarını değerlendirebileceğime inanıyorum" başlığı altında fikirlerini beyan etmişlerdir. Öğretmen adayları "kesinlikle katılıyorum" veya "katılıyorum" ifadelerini kullanarak çoktan seçmeli testler, açık uçlu sorular, yazılı raporlar, kavram haritaları, projeler, performans değerlendirme gibi bir çok değerlendirme yöntem ve tekniğini kullanarak öğrenci başarılarını değerlendirebileceğini belirtmişken öğretmen adaylarının \%31 i "kesinlikle katılmıyorum" veya "katılmıyorum" ifadelerini kullanarak "akran değerlendirmeyi" etkili olarak kullanamayacaklarını \% 20 ye yakını ise rubrik, ve diyagramı, yapılandırılmış grid, tanılayıcı dallanmış ağaç, ve tutum ölçeklerini etkili olarak kullanamayacaklarını belirtmişlerdir.

Sınıf deneyimi boyutunda öğretmen adayları "Şu anki deneyimlerime göre sınıf yönetimi açısından aşağıdaki belirtilen durumlarla ilgili problemlerin üstesinden gelebileceğime inanıyorum" başlı̆̆ı altında fikirlerini beyan etmişlerdir. Öğretmen adayları "kesinlikle katıllyorum" veya "katılıyorum" ifadelerini kullanarak etkili iletişim, öğrencilerin aktif olması, öğrenciler arasındaki bilimsel tartışmalar, öğrencilerin çalışmaları esnasındaki görev paylaşımları gibi sınıf yönetimi ile ilgili bir çok problemin üstesinden gelebileceklerini belirtmişken öğretmen adaylarının \% 15-20 ye yakını ise "kesinlikle katılmıyorum" veya "katılmıyorum" ifadelerini kullanarak öğrenme farklılıkları, öğrenciler arasındaki kültürel farklar, sınıftaki fiziksel ortam ve düzenlemeler ve velilerin istekleri ile ilgili problemin üstesinden gelemeyeceklerini belirtmişlerdir. Bunun yanı sıra ilginç bir şekilde öğretmen adaylarının \%95 i "öğrencilerin aralarında konuşması" ile \%90 1 da "öğrencilerin merakı" ile ilgili problemin üstesinden gelemeyeceklerini belirtmişlerdir.

Fen bilimleri konuları boyutunda öğretmen adayları "Şu anki bilgilerime göre aşağıdaki konuları etkili bir şekilde öğretebileceğime inanıyorum" başlığı altında fikirlerini beyan etmişlerdir. Öğretmen adaylarının yaklaşık \%15-20 si "kesinlikle katılmıyorum" veya "katılmıyorum" ifadelerini kullanarak, kayaçlar, madenler ve teknoloji, fosiller, toprak çeşitleri ve erozyon, yeraltı ve yer üstü su kaynakları, gök cisimleri, güneş sistemi, uzay ve yaşam, uzay teknolojisi, uzay kirliliği, dünyanın oluşum süreci, iklim ve hava olayları ve meteorolojinin günlük hayattaki önemi konularını etkili olarak öğretemeyeceklerini belirtmişlerdir.

Fen bilimleri öğretmen adaylarının fen öğretimine ilişkin özyeterlilik inanç düzeyi ortalamasının bireysel fen öğretimi özyeterliliği açısından düşük seviyede ve sonuç beklentisi bakımından orta seviyede olduğu sonucuna ulaşılmıştır. Özkan, Tekkaya ve Çakıroğlu (2002), fen bilgisi öğretmen adaylarının fen kavramlarını anlama düzeyleri, fen öğretimine yönelik tutum ve öz-yeterlik inançlarının araştırıldığ 1 çalışmasında fen bilimleri öğretmen adaylarının fen öğretimi öz yeterlilik inançlarının pozitif düzeyde olduğu, Olgan, Güner-Alpaslan ve Öztekin (2014) ise okul öncesi öğretmen adaylarının bireysel fen öğretimi özyeterlik ve sonuç beklentisi inançlarının orta düzeyde olduğunu sonucuna ulaşmışıır ve fen konularını etkin bir şekilde öğretebileceklerini ve etkinliklere ilişkin soruları cevaplamakta zorlanmayacaklarını ifade etmişlerdir.

$\mathrm{Bu}$ çalışmanın diğer bir sonucu, fen bilimleri öğretmen adaylarının fen başarı puanı (GPA)

23 | P a g e

www.iiste.org 
ortalamasının orta seviyede olduğudur. Gökdemir (2020), 236 fen bilimleri öğretmen adayının PISA fen okuryazarlığının araştırılması amacıyla yaptığı araştırmasında katılımcıların akademik ortalama dağılımının 4,00'lük sistemde 3,01 ve 3,50 not aralığında ve öğretmen yetiştirme program derslerinde öğretmen adaylarının yüksek başarı düzeyine sahip olduğunu belirtmiştir. Tenaw (2013)'ın, eğitim fakültesi ikinci sınıf öğrencileriyle yaptığı araştırma sonucunda öğrencilerin özyeterlik seviyesinin orta düzeyde olduğu ve özyeterlik ve akademik başarı arasında anlamlı bir ilişki olduğu sonucuna ulaşmıştır.

$\mathrm{Bu}$ çalışmada aynı zamanda fen bilimleri öğretmen adaylarının fen bilimleri konularını öğretebilmelerine yönelik inançları, akademik başarı puanı, bireysel fen öğretimine yönelik özyeterlik ve fen öğretiminde değerlendirmeye yönelik inançları değişkenleri çoklu doğrusal regresyon analizinde anlamlı yordayıcılar olduğu sonucuna ulaşılmıştır. Saracaloğlu, Yenice ve Özden (2013), 'in, fen bilgisi öğretmen adaylarının fen ve teknoloji okuryazarlığına ilişkin öz yeterlik algıları ile fen'e yönelik tutumları arasındaki ilişkiyi incediği çalışmada, fen bilimleri öğretmen adaylarının fen ve teknoloji okuryazarlığına ilişkin öz yeterlik algılarının "oldukça yeterli” düzeyde olduğu belirtilmiştir. Bununla birlikte,fen bilimleri ögretmen adaylarının fen bilimleri okuryazarlık öz yeterlik algılarının sınıf düzeyine göre istatistiksel olarak anlamlı bir farklılık gösterdiği sonucuna ulaşılmıştır. Ayrıca, fen bilimleri öğretmen adaylarının fen bilimleri okuryazarlık öz yeterlik algısı puanları ile fene yönelik tutum arasında pozitif yönlü ve orta seviyede bir ilişki olduğu sonucuna ulaşılmıştır.

Çoklu regresyon analizi sonuçları fen bilimleri öğretmen adaylarının fen okuryazarlık puanlarındaki varyansın en iyi açıklayıcısının akademik başarı puanı değişkeni olduğunu göstermektedir. Akademik başarı puanı yüksek olan öğretmen adaylarının fen okuryazarlık puanının, akademik başarı puanı düşük olan öğretmen adaylarının fen okuryazarlık puanından daha fazla olduğu sonucuna ulaşılmıştır. Yolagiden (2017), fen öğrenme becerisi yükseldikçe fen okuryazarlık düzeylerinin yükseldiğini belirtmiştir. Buna karşın Bacanak (2002) çalışmasında, fen okuryazarlığı testinde erkek öğretmen adaylarının kadın öğretmen adaylarına nazaran daha başarılı olduğunu belirtmiştir. Bununla birlikte; genel not ortalamasının fen okuryazarlık düzeyi üzerinde etkili olmadığını belirtmiştir.

Çoklu regresyon analizi sonuçları fen okuryazarlık puanının en iyi ikinci yordayıcısı veya fen okuryazarlık puanındaki varyansın en iyi ikinci açıklayıcısı fen bilimleri konularını öğretmeye yönelik inanç değişkenidir. Fen bilimleri konularını öğretmeye yönelik inanç düzeyi yüksek olan öğretmen adaylarının fen okuryazarlık puanının, fen bilimleri konularını öğretmeye yönelik inanç düzeyi düşük olan öğretmen adaylarının fen okuryazarlık puanına nazaran daha yüksek olduğu sonucuna ulaşılmıştır. Öğretmen adayları fen bilimleri konularının içeriğine yönelik bilgi düzeyleri yüksekse, ilgili fen bilimleri konularını öğretmeye yönelik inanç düzeyinin yüksek olduğu düşünülmektedir. Yağan (2019) da fen edebiyat fakültesi mezunu öğretmenlerinin fen okuryazarlığına ilişkin özyeterlik algılarının, eğitim fakültesinden mezun öğretmenlerin özyeterlik algılarından daha yüksek olduğunu belirtmiştir.

Çoklu regresyon analizi sonuçlarına göre fen okuryazarlık puanının en iyi üçüncü ve dördüncü yordayıcısı veya fen okuryazarlık puanındaki varyansın en iyi üçüncü ve dördüncü açıklayıcısı sırasıyla fen öğretimine yönelik bireysel özyeterlilik ve fen öğretimine yönelik inancın değerlendirme alt boyutu değişkenidir. Fen öğretimine yönelik bireysel özyeterlilik değişkeni incelendiğinde öğretmen adaylarının fen okuryazarlık puanlarındaki artışta, fen öğretimine yönelik bireysel özyeterlilikte düşüş olmaktadır. Öğretmen adaylarının fen okur yazarlığı düzeyi arttıkça bilime şüpheci yaklaşıyor olabilirler bu da fen öğretimine yönelik bireysel özyeterlilikte düşüşe neden olabildiği düşünülmektedir. Morell ve Caroll (2003), öğretim yöntemleri, öğretmenlik uygulaması ve alan derslerinin fen bilimleri öğretmen adaylarının fen öğretimine yönelik öz-yeterlik inançlarına olan etkisini araştırmışlardır. Veriler Riggs ve Enochs (1990)'un geliştirdiği fen öğretimi öz-yeterlik inancı ölçeği ile toplanmıştır. Öğretim yöntemleri dersinin fen bilimleri öğretmen adaylarının fen öğretimine yönelik bireysel özyeterliklerinin gelişimi üzerine anlamlı bir etkisinin olduğu belirtilmiştir. Fettahlıŏglu, Güven, İnce-Aka, Sert-Çıbık ve Aydoğdu (2011)' nun fen bilgisi öğretmen adayları ile gerçekleştirdiği çalışmada öğretmen adaylarının fen öğretimine yönelik bireysel özyeterlik ve sonuç beklentisine yönelik inançlarının yeterli düzeyede olmadığı ve fen öğretimine yönelik öz-yeterliliğin fen bilimleri öğretmen adaylarının akademik başarısını pozitif yönde anlamlı olarak yordadığı sonucuna ulaşılmıştır. Bunun yanı sıra fen bilimleri dersinde alternatif ölçme değerlendirme yöntemlerini kullanabileceğine yönelik inanç düzeyi yüksek olan öğretmen adaylarının fen okuryazarlık puanının, fen bilimleri dersinde geleneksel ölçme değerlendirme yöntemlerini kullanabileceğine yönelik inancı yüksek olan öğretmen adaylarının fen okuryazarlık puanına nazaran daha yüksek olduğu sonucuna ulaşılmıştır.

Fen Bilgisi öğretmen adayları kayaçlar, madenler ve teknoloji, fosiller, toprak çeşitleri ve erozyon, yeraltı ve yer üstü su kaynakları, gök cisimleri, güneş sistemi, uzay ve yaşam, uzay teknolojisi, uzay

24 | P a g e

www.iiste.org 
kirliliği, dünyanın oluşum süreci, iklim ve hava olayları ve meteorolojinin günlük hayattaki önemi konularını etkili olarak öğretemeyeceklerini belirtmişlerdir. $\mathrm{Bu}$ nedenle üniversitelerde bu konularla ilgili içerik bilgisini arttıracak şekilde ve öğretmenlerin alternatif ölçme değerlendirme yöntemlerini öğrenip uygulayabileceği seçmeli dersler konulmalıdır. Yetişir (2007), araştırmasında fen bilimleri öğretmenliği bölümünde okuyan öğrencilerinin fen okuryazarlığı düzeylerinin cinsiyete bağlı olmadığ1 sonucuna ulaşmıştır. Kocaoğlu (2011), fen bilimleri öğretmen adaylarının fen bilimleri başarı testi cevaplarıyla cinsiyetleri arasında istatistiksel olarak anlamlı bir fark olmadığı sonucuna ulaşmıştır. Fen bilimleri öğretmenlerinin fen okuryazarlığı düzeyi cinsiyet, hizmet yılı ve okul çeşidi gibi değişkenler açısından daha geniş bir örneklemle araştırılmalıdır.

\section{Kaynakça}

Aldan Karademir, Ç. (2013). Öğretmen adaylarının sorgulama ve eleştirel düşünme becerilerinin ögretmen öz yeterlik düzeyine etkisi. Yayımlanmamış Doktora Tezi, Adnan Menderes Üniversitesi/Sosyal Bilimler Enstitüsü, Aydın.

Bacanak, A. (2002). Fen bilgisi öğretmen adaylarının fen okuryazarlıkları ile fen teknoloji-toplum dersinin uygulanışını değerlendirmeye yönelik bir çalışma. Yayımlanmamış Yüksek Lisans Tezi, Karadeniz Teknik Üniversitesi Fen Bilimleri Enstitüsü, Trabzon.

Bandura, A. (1997). Self-efficacy: Toward a unifying theory of behavioral change. Psychological Review, 84(2), 191-215.

Demirtaş,H., Cömert, M. ve Özer, N. (2011). Öğretmen adaylarının özyeterlik inançları ve öğretmenlik mesleğine ilişkin tutumları. Eğitim ve Bilim Dergisi, 36(159), 96-111.

Ekici, G. (2008). Sınıf yönetimi dersinin öğretmen adaylarının öğretmen öz-yeterlik algı düzeyine etkisi. Hacettepe Üniversitesi, Ĕ̆itim Fakültesi Dergisi, 35, 98-110.

Fettahlığlu, P., Güven, E., İnce-Aka, E., Sert-Çıbık, A. ve Aydoğdu, M. (2011). Fen bilgisi öğretmen adaylarının fen öğretimine yönelik öz-yeterlik inançlarının akademik başarı üzerine etkisi. Kırşehir Üniversitesi Ĕgitim Fakültesi Dergisi, 12(3), 159-175.

Gökdemir, H. (2020). Fen bilimleri öğretmen adaylarının PISA fen okuryazarlı̆̆ yeterliliklerinin araştırılması. Yayımlanmamış Yüksek Lisans Tezi, Hacettepe Üniversitesi Eğitim Bilimleri Enstitüsü, Ankara.

Güçlüer, E. (2012). Fen ve teknoloji dersinde "vücudumuzda sistemler" ünitesinde fen okuryazarlı̆̆ını geliştirici etkinliklerin kullanılmasının başarıya, tutuma ve bilimsel süreç becerilerine etkisi. Yayımlanmamış Doktora Tezi, Dokuz Eylül Üniversitesi Eğitim Bilimleri Enstitüsü, İzmir.

Karaduman, A. (2015). Üniversite ögrrencilerinin yaşam boyu öğrenme ĕgilimleri ile özyeterlik algıları arasındaki ilişki. Yayımlanmamış Yüksek Lisans Tezi, Bartın Üniversitesi Eğitim Bilimleri Enstitüsü, Bartın.

Kaya, M. ve Bacanak, A. (2013). Fen ve teknoloji öğretmen adaylarının düşünceleri: Fen okuryazarı birey yetiştirmede öğretmenin yeri. Dicle Üniversitesi Ziya Gökalp Ĕ̈itim Fakültesi Dergisi, 21, 209-228.

Kocaoğlu, G. (2011). Fen bilgisi öğretmenliği 1. ve 4. sinıf ögretmen adaylarının fen bilgisi başarılarl, fen bilgisi ögretimine yönelik tutumları, üniversiteye giriş başart ve not ortalamaları arasındaki ilişki. Yayımlanmamış Yüksek Lisans Tezi, Uşak Üniversitesi Sosyal Bilimler Enstitüsü, Uşak. 
Kurnaz, Ş. (2019). Fen bilgisi ögrretmen adaylarının fen okuryazarllğg ve alan bilgisi yeterliliklerinin karşslaş̧tırılması: SDÜ-MAKÜ Örneği. Yayımlanmamış Yüksek Lisans Tezi, Süleyman Demirel Üniversitesi Eğitim Bilimleri Enstitüsü, Isparta.

Küçük, A. ve Demir, B. (2009). İlköğretim 6-8. sınıflarda matematik öğretiminde karşılaşılan bazı kavram yanılgıları üzerine bir çalışma. Dicle Üniversitesi Ziya Gökalp Eğitim Fakültesi Dergisi, 13, 97-112.

Laugksch, R. C. \& Spargo, P. E. (1996). Construction of a paper-and-pencil test of basic scientific literacy based on selected literacy goals recommended by the American association for the advancement of science. Public Understanding of Science, 5(4), 331-359.

Milli Eğitim Bakanlığı (2013). İlköğretim Fen ve Teknoloji Programı. Talim Terbiye Kurulu, Ankara.

Morrell, P. D. ve Carroll, J. B. (2003). An extended examination of preservice elementary teachers' science teaching self- efficacy. School Science and Mathematics, 103(5), 246-251.

Olgan, R., Güner-Alpaslan, Z., Öztekin, C. (2014). Okul öncesi öğretmen adaylarının fen öğretimine yönelik sonuç beklentisi inançlarını etkileyen faktörler. Eğitim ve Bilim, 39(173), 288-300.

Özkan, Ö. Tekkaya, C. ve Çakıroğlu, J. (2002). Fen bilgisi aday öğretmenlerin fen kavramlarını anlama düzeyleri, fen ögretimine yönelik tutum ve öz-yeterlik inançları, V. Fen Bilimleri Eğitimi Kongresi, Orta Doğu Teknik Üniversitesi, Ankara.

Özdemir, O. (2010). Fen ve teknoloji öğretmen adaylarının fen okuryazarlığının durumu. Türk Fen Ĕ̈itimi Dergisi,7(3), 42-56.

Riggs, I. M. and Enochs, L. G. (1990). Toward the development of an elementary teacher's science teaching efficacy belief instrument. Science Education, 74(6), 625-637.

Saracaloğlu, A. S., Yenice, N. ve Özden, B. (2013). Fen bilgisi öğretmen adaylarının fen ve teknoloji okuryazarlığına ilişkin öz yeterlik algıları ile fene yönelik tutumları arasındaki ilişki. International Journal of New Trends in Arts, Sports \& Science Education, 2(1), 58-69.

Skaalvik, E. M. ve Skaalvik, S. (2010). Teacher self-efficacy and teacher burnout: A study of relations. Teaching and Teacher Education, 26(4), 1059-1069.

Tekkaya, C., Cakiroğlu, J. \& Özkan, Ö. (2004). Turkish pre-service science teachers’ understanding of science and their confidence in teaching it. Journal of Education forTeaching, 30(1), 57-66.

Tenaw, Y. A. (2013). Relationship between self-efficacy, academic achievement and gender in analytical chemistry at Debre Markos College of Teacher Education. African Journal of Chemical Education, 3 (1), 3-28.

Yağan, A. (2019). Fen bilimleri öğretmenlerinin fen okuryazarlı̆ğ ve özyeterlik algllarının karşılaş̧ırmalı incelenmesi. Yayımlanmamış Yüksek Lisans Tezi, Gazi Üniversitesi Eğitim Bilimleri Enstitüsü, Ankara.

Yener, D. ve Yılmaz, M. (2017). Öğretmen adaylarının öğrenme öğretme anlayışları ve fen öğretimine yönelik özyeterlik inançları. Abant İzzet Baysal Üniversitesi Eğitim Fakültesi Dergisi, 17 (2), 1016-1038.

Yenice, N. (2012). Öğretmen adaylarının öz-yeterlik düzeyleri ile problem çözme becerilerinin incelenmesi. Elektronik Sosyal Bilimler Dergisi, 11(39), 36-58.

26 I P a g e

www.iiste.org 
Yeşilyurt, E. (2013). Öğretmen adaylarının öğretmen öz-yeterlik algıları. Elektronik Sosyal Bilimler Dergisi , 12(45), 88-104.

Yetişir, M. İ. (2007). Illköğretim fen bilgisi öğretmenliği ve sinıf öğretmenliği birinci sinıfinda okuyan ögretmen adaylarının fen ve teknoloji okuryazarlık düzeyleri. Yayımlanmamış Yüksek Lisans Tezi, Gazi Üniversitesi Eğitim Bilimleri Enstitüsü, Ankara.

Yılmaz, M. (2014). Öğretmen adaylarının öğrenme stillerinin öğrenme öğretme anlayışları ve fen ögretimine yönelik özyeterlik inançları ile ilişsisi. Yayımlanmamış Yüksek Lisans Tezi, Abant İzzet Baysal Üniversitesi Eğitim Bilimleri Enstitüsü, Bolu.

Yılmaz, M. ve Eren, A. (2014). Sınıf öğretmen adaylarına basit elektrik devreleri konusunun simülasyon ve laboratuvar uygulaması teknikleriyle öğretimi. Trakya Üniversitesi Eğitim Fakültesi Dergisi, 4(2), 84-99.

Yılmaz-Tüzün, Ö. (2008). Preservice elementary teachers' beliefs about science teaching. Journal of Science Teacher Education, 19(2), 183-204.

Yolagiden, C. (2017). Öğretmen adaylarının fen öğrenme becerisi, fen okuryazarlĭg ve sosyobilimsel konulara yönelik tutumları arasındaki ilişskinin araştırılması. Yayımlanmamış Yüksek Lisans Tezi, Sütçü İmam Üniversitesi Fen Bilimleri Enstitüsü, Kahramanmaraş. 